— 総説

\title{
たこつぼ型心筋症
}

\section{Takotsubo cardiomyopathy}

\section{藤岡重和 1） 大中玄彦 2） 和田晋一 3)}

\section{Shigekazu Fujioka1) Haruhiko Onaka2) Shinichi Wada ${ }^{3)}$}

1）大阪保健医療大学保健医療学部リハビリテーション学科

干530-0043 大阪市北区天満 1 丁目 9 番 27 号

TEL: 06-6352-0093 Fax: 06-6352-5995

E-mail: shigekazu.fujioka@ohsu.ac.jp

2）高槻赤十字病院循環器内科

3）香川県立保健医療大学保健医療学部臨床検査学科

1) Department of Rehabilitation Science, Faculty of Allied Health Sciences, Osaka Health Science University 1-9-27 Temma, Kita-ku, Osaka, 530-0043, Japan

Phone: +81-6-6352-0093

2) Department of Cardiology, Takatsuki Red Cross Hospital

3) Department of Medical Technology, Faculty of Health Sciences, Kagawa Prefectural University of Health Sciences

保健医療学雑誌 8 (1): 64-72, 2017. 受付日 2017 年 2 月 10 日 受理日 2017 年 3 月 10 日

JAHS 8 (1): 64-72, 2017. Submitted Feb. 10, 2017. Accepted Mar. 10, 2017.

\section{ABSTRACT:}

First described in Japan in the early 1990s, takotsubo cardiomyopathy (TTC) has gained worldwide recognition. TTC is typically precipitated by a transient ballooning of the left ventricular apex after an emotional or physical trigger. A dramatic and characteristic hallmark of TTC is the complete reversibility of ventricular contraction abnormalities within days to weeks. Since the clinical presentation, electrocardiographic findings, and lab tests are often similar to those of acute myocardial infarction (AMI) or acute myocarditis, differential diagnosis is needed to exclude other diseases. Although TTC has been recognized as a benign condition, it is now characterized by substantial morbidity and mortality, which equal those of AMI. In the acute phase, patients are prone to severe complications, such as cardiogenic shock, cardiac rupture and fatal arrhythmia. Therefore monitoring the clinical course is essential to prevent or treat acute complications. Health care professionals also need to consider that TTC onset in a healthcare setting can occur during outpatient medical evaluation or hospitalization for acute illness. This review article summarizes pathophysiology, clinical features, diagnostic evaluation, and treatment of TTC.

Key words: takotsubo cardiomyopathy, stress cardiomyopathy, myocarditis 
要旨 :

たこつぼ型心筋症はわが国で発見され，世界に発信された心疾患である。精神的，身体的ストレスを誘因とし，急性 心筋梗塞に類似した前胸部痛と心電図異常で発症する. 典型例では, 左室心尖部の風船状膨隆と心基部の過収縮という 特異な収縮形態を呈するが, こうした収縮異常は可逆的で, 通常数週間で正常化することが本症の特徵である. 当初, 予後良好な疾患と考えられていたが，急性期に心原性ショック，心破裂をきたし死亡することがあり，急性心筋梗塞に 準じた経過観察の必要性が再認識されるようになった。最近では, 運動負荷などの検査, 手術, 精神科治療などの医療 行為, 自然災害による発症が国内外より多数報告されており, 本症はどの診療科においても遭遇する可能性がある。本 稿では，たこつぼ型心筋症の病態，急性期診断，治療，予後なじを中心に概説する.

キーワード : たこつぼ型心筋症，ストレス心筋症，心筋炎

\section{疾患概念}

たこつぼ型心筋症は 1990 年代にわが国で疾患 概念が確立され ${ }^{1-3)}$, 現在では国際的に広く認識 された心病態である。典型例では精神的あるいは 身体的ストレスを契機に，急性心筋梗塞に酷似し た胸痛と心電図変化で発症する。 心エコー検査あ るいは左室造影検査を行うと, 左室の収縮異常の 形態が日本古来の蛸盇漁で使われる素焼きの蛸 盇に似ていることから，たこつぼ型心筋症の命名 がなされた。こうした左室壁運動異常は, 通常数 週間で回復することが本症の特徵である. 海外で は, 心尖部バルーニング症候群（apical ballooning syndrome), ストレス心筋症 (stress cardiomyopathy), 傷心症候群 (broken heart syndrome）と呼ばれることも多い. 中高齢の男性 に多い心筋梗塞等の急性冠症候群 (acute coronary syndrome) と異なり, 高齢女性に多く発 症することが知られている. 本症の頻度は急性冠 症候群の約 $2 \%$ とれるが, 僅かな症状での発症も あるため見逃されている症例も多いと推定され る. 現在では, 検查, 処置, 治療などの医療行為, 地震などの自然災害による発症例も国内外より 多数報告されている. 本症の発症機序は未だ不明 であるが，ストレスによる交感神経機能六進説が 有力視されている．たこつぼ型心筋症は検查や治 療中に発症することが稀ではなく, どの診療科に おいても遭遇する可能性がある。

\section{発症機序}

たこつぼ型心筋症は, わが国で発見され世界に 発信された心疾患であるが, 発症機序の詳細は未 だ不明である. 冠攣縮説, 微小循環障害説, カテ コラミン心筋障害説，エストロゲン減少説，交感 神経機能充進説などが提唱されている. 現在, 交
感神経機能六進説が有力視されており, ストレス により中枢神経から心臓交感神経に強い刺激が 送られ，心臟に限局したカテコラミン過剰放出が 発症の契機となるとされる ${ }^{4)}$. 実際に，たこつぼ 型心筋症患者で, 血中ノルエピネフリンおよびエ ピネフリン濃度の増加が報告されている ${ }^{4)}$. Paur らは多量のエピネフリンが心尖部に多く分布す る $\beta_{2}$ アドレナリン受容体を刺激し, 抑制性 $G$ 蛋 白へのシグナルスイッチを惹起し, 心尖部の無収 縮を引き起こすと推測している ${ }^{5)}$. シグナルスイ ッチ現象は慢性的な $\beta$ 受容体刺激は protein kinase A を介して抑制性シグナルに切り替わると いう概念である ${ }^{6)}$. 一方，ノルエピネフリンを介 する $\beta_{1}$ 受容体刺激が心基部過収縮を引き起こす と説明している。実際に, Paur らはラットの実験 で，多量のエピネフリン投与が，たこつぼ型心筋 症類似の病態を引き起こすことを確認している ${ }^{5)}$. また，閉経後の女性に多く発症することから，エ ストロゲン減少による心保護作用の欠如が本症 の発症に強く関与していると考えられている. 最 近, Suzuki らは, 本症患者の急性期の脳 SPECT に おいて, 脳血流が海馬, 大脳基底核, 脳幹で増加 し, 前頭前皮質で減少していることを見出した ${ }^{7)}$. ストレスによる心脳連関のさらなる病態解明が またれる。しかし，ストレス誘因がなく発症する 場合があり，左室壁運動異常にバリエーションが あり心尖部以外の様々な部位に収縮異常をみる ことから, 病態解明が進めば本症は異なる病因に よる複数の疾患として分類される可能性も考え られる。

\section{心筋病理}

心筋逸脱酵素の上昇より心筋組織障害が生じ ていることは容易に推定されるが，本症急性期に 心筋生検を実施し検討した報告は少ない。 
Yoshida らは 9 例の心筋生検で，4 例に心筋線維 症，3 例に単核球浸潤，4 例に筋収縮帯壊死を認 め全例で有意な炎症性細胞浸潤，心筋壊死はなか ったと報告している ${ }^{8)}$ 。一方，von Korn らは 5 例 の心筋生検において, ダラス基準を満たす細胞浸 潤（心筋炎）を2 例に認めたと報告している ${ }^{9)}$. Akashi らは 5 例の心筋生検を検討し，2 例で心筋 炎を示唆するとしている ${ }^{10)}$. Wittstein らは，5 例の心筀生検において，4 例で単核球，マクロフ アージ浸潤，筋収縮帯形成を認め，1 例で広範な リンパ球浸潤，筋収縮帯壊死を認めている ${ }^{4)}$. Nef らは 8 症例において, 急性期と回復期の心筋生検 像を検討した ${ }^{11)}$ 。急性期に，心筋細胞肥大，グリ コーゲン顆粒の蓄積, 収縮蛋白, 細胞骨格蛋白の 障害, 細胞外マトリクスの増加を認めたが, 回復 期の心筋生検では，これらの障害像はほぼ完全に 回復していたと報告している。筋内蛋白発現に ついて，急性期に $\alpha$-actin, titin が心筀細胞の 辺縁に偏り connexin-43 の発現が低下するが，回 復期では，これらの蛋白発現と分布は改善すると 述べている．間質の変化は急性期にフィブロネク チンが増加し, CD68 陽性マクロファージの浸潤が みられるが，回復期では改善傾向を示すと報告し ている. Kawai は国内諸施設より検鏡を許可され た 7 剖検例を検討した ${ }^{12)}$. 心筋病変の特徵は個々
の心筋細胞および心筋細胞群を主体とし，好酸性 染色性の亢進，筋収縮帯形成，壊死，断裂などを 示したと報告している。同一心室レベルでは，病 変はほぼ全周性に広がり心室長軸では心基部よ り心尖部で強い傾向を示したという。しかし，心 筋生検例、剖検例が少ないこともあり，本症の診 断根拠となる病理組織所見は未だ報告されてい ない.

\section{診断基準}

日本循環器学会と Mayo Clinic から診断基準 13,14) が提唱されているが, 国際的には Mayo Clinic による診断基準（Table 1）が汎用されている. いずれの基準でも特徵的な臨床所見と冠動脈疾 患の除外を重視している。また，褐色細胞腫，心 筋炎は除外としている。脳血管疾患については扱 いが異なり，日本循環器学会の基準では除外とし ているが，Mayo Clinic の基準では除外項目に入 れていない。最近，欧州心臓病学会より診断基準 15)が発表された。この基準では褐色細胞腫, 脳血 管疾患に伴うものも含めており，たこつぼ症候群 (takotsubo syndrome) と呼称することを推奨して いる.

Table I. Mayo Clinic criteria for apical ballooning syndrome (ABS)

1. Transient hypokinesis, akinesis, or dyskinesis of the left ventricular mid segments with or without apical involvement; the regional wall motion abnormalities extend beyond a single epicardial vascular distribution; a stressful trigger is often, but not always present. *

2. Absence of obstructive coronary disease or angiographic evidence of acute plaque rupture. $\dagger$

3. New electrocardiographic abnormalities (either ST-segment elevation and/or T-wave inversion) or modest elevation in cardiac troponin.

4. Absence of:
a. Pheochromocytoma

b. Myocarditis

In both of the above circumstances, the diagnosis of ABS should be made with caution, and a clear stressful precipitating trigger must be sought.

*: There are rare exceptions to these criteria such as those patients in whom the regional wall motion abnormality is limited to a single coronary territory.

$\dagger$ : It is possible that a patient with obstructive coronary atherosclerosis may also develop ABS. However, this is very rare in our experience and in the published literature, perhaps because such cases are misdiagnosed as an acute coronary syndrome. 


\section{病型}

たこつぼ型心筋症は，様々な壁運動異常のバリ エーションが報告されるようになり，心尖部型 (apical type)，心室中部型 (mid-ventricular type），心基部型（basal type），局所型（focal type）に分類されている. 心尖部型が最も多く, 左室心基部の過収縮と心尖部無収縮を呈する。左 室中部，心基部，左室の一部に収縮異常（無収縮） を認めるものを心室中部型，心基部型，局所型と いう. Templin らは米国と欧州 9 力国 26 施設 1750 症例を検討した結果, 心尖部型 1430 症例 (81.7\%), 心室中部型 255 症例（14.6\%），心基部型 39 症例

(2. $2 \%)$ ，局所型 26 症例（1.5\%） と報告してい る ${ }^{16)}$. わが国では, Kato らが 144 症例を検討し, 心尖部型 85 症例 (59.0\%) ，心室中部型 49 症例 (34.0\%)，心基部型 0 症例（0\%），局所型 10 症 例（6.9\%） と報告している ${ }^{17)}$. 病型の頻度は報告 により様々であるが，心尖部型が全体の約 8 割を 占めると考えられている。

\section{臨床症状}

たこつぼ型心筋症の誘因は多岐にわたるが，精 神的ストレスと身体的ストレスに大別される. 肉 親の死亡, 離婚, 激しい口論, 法廷闘争, 引っ越 しなどの精神的ストレス，てんかん，喘息重積発 作，慢性閉塞性肺疾患の急性増悪，感染症，悪性 疾患，骨折や尿路結石に伴う激痛などの身体的ス トレスが誘因となる。一部には朗報を誘因とする 報告もあり happy heart syndrome と呼ばれてい る.しかし, 全体の約 3 割の症例では, 明確なス トレス誘因がなく発症している。最近では，運動 負荷，ドブタミン負荷心エコー，気管支鏡などの 検査, 内科、精神科治療, 血液透析, 気管内挿管, 分婏, 手術などの医療行為, 地震などの自然災害 での発症例も多数報告されている。おが国では, 2004 年, 新潟中越地震後に被災地近郊で患者数が 急増した ${ }^{18)}$ 。また，術後の急変などに本病態が関 与している可能性も推定されている. 疫学研究に よると, たこつぼ型心筋症では不安障害, 気分障 害，うつ，アルコール依存症，薬物依存症を有す る症例が多いことが明らかにされている ${ }^{16,19)}$. 精 神疾患の既往例では，医療行為などが誘因となり 本症発症の可能性があること念頭におく必要が
ある。発症は季節では夏が多く，発症時間では朝 が多いとの報告もある。初発症状は胸痛，胸部不 快感, 呼吸困難, 動悸, 全身倦总感が多い。胸痛 は急性心筋梗塞と似ているが，比較的軽度で長く 持続する傾向がある。ニトログリセリンは無効で ある. 発症時の症状が軽微で, 数日後に心不全を きたし本症と診断されることもある．急性期に心 房細動，心房粗動，房室ブロック，心室頻拍，心 室細動など多彩な不整脈を合併し，動悸，意識消 失などの症状を呈することがある，また，心室壁 在血栓により全身の塞栓症をきたし，急性期に抗 凝固療法が必要となる症例もある。しかし, 無症 状あるいは僅かな症状での発症例も少なくない ため，診断に至らない症例も多いと推定される.

\section{臨床検査}

\section{1）血液検査}

血液検查では，急性期に creatine phosphokin ase (CPK), aspartate aminotransferase (AST), lactate dehydrogenase（LDH）などの心筋逸脱酵 素の上昇を認める. CPK 分画のなかでも $\mathrm{CPK}-\mathrm{MB}$ は 心筋特異性が高い。これらの上昇パターンは急性 心筋梗塞に類似するが，最大 CK 值は通常 1,000 IU/L 以下である。心筋トロポニンや heart-type fatty acid-binding protein (H-FABP) も上昇す るが比較的軽度である。しかし，心筋逸脱酵素や 心筋卜ロポニンの初回測定值からは急性心筋梗 塞との鑑別は困難である。一方, brain natoriur etic peptide (BNP), あるいは N-terminal proBNP（NT-proBNP）は著明に高值を示す．壁運動異 常の程度に比べて $\mathrm{CPK}-\mathrm{MB}$ ，トロポニンなどの心筋 障害マーカーの上昇は軽微であり，BNP/心筋卜ロ ポニン $\mathrm{T}$ 比が急性心筋梗塞との鑑別に有用との報 告もある ${ }^{20)}$. 血中カテコラミンは上昇しない症例 もあるため，血中カテコラミン測定は本症診断の 一助となるものの診断根拠とはならない.

\section{2 ）心電図}

心電図は簡便かつ非侵襲であり，胸痛患者に最 初に行われる臨床検査である。心尖部型では，急 性期に前胸部誘導を中心に広範な ST 上昇がみら れる (Fig. 1)。発症 1〜2 日後には，T 波が陰転し QT 延長を伴う。一過性の Q 波を形成することもあ る。 その後, 一旦陰性 $\mathrm{T}$ 波は浅くなるが，再び顕 
著（巨大陰性 T 波）となる。発症 2-3 週後に巨大 陰性 T 波はピークとなる。通常，これらの心電図 変化は数ヶ月以内に正常となる. 本症急性期の心 電図は，左冠動脈前下行枝閉塞による急性心筋梗 塞の心電図と酷似するため両者の鑑別が必要で ある.たこつぼ型心筋症では, V1-V3 よりも V4-V6 でより ST 上昇の程度が大きく, 異常 $\mathrm{Q}$ 波が少な い傾向がある. Kosuge らは，たこつぼ型心筋症の 心電図上の特徵は，aVR 誘導で ST 低下を認め，V1 誘導で ST 上昇を認めないことであると報告して いる，両者の存在は，本症を診断するうえで，感 度 $91 \%$ ，特異度 $96 \%$ ，陽性的中率 95\%であるという 21)。Zorzi らは，PR 部分の低下と $2 \mathrm{~mm}$ 以下の軽度 ST 上昇の所見が，急性心筋梗塞との鑑別に有用 であると述べている ${ }^{22)}$. また, 急性期の心電図に おける J 波の存在は，心死亡や心室性不整脈の指 標となることが報告されている ${ }^{23)}$ 。 心室中部型, 心基部型，局所型の収縮形態を示すたこつぼ型心 筋症の心電図に関する見解は確立されていない.

\section{3 ）心エコー}

心エコーは最初に行われる非侵襲的画像検査 である。たこつぼ形態を描出するには，左室前壁 と後壁からなる心尖部二腔像を用いて，心尖部か ら左室中部の壁運動が対称的に障害されている ことを示すとよい，壁運動異常は時間経過ととも に改善し，通常数週間で回復することが本症の特 徵である。心エコー検査による経過観察のポイン 卜は，壁運動の改善を追うことと合併症の有無を 確認することである。たこつぼ型心筋症の合併症 として左室流出路閉塞，心尖部血栓，心破裂など がある。また，本症の約 $1 / 3$ の症例に右室心尖部 に無収縮病変を認め，より重症例に多いことから 右室の観察も必要である.

\section{4 ）心臟 MRI}

シネMRI を用いて，たこつぼ型心筋症に特徵的 な心収縮動態が経時的に評価できる。また，心臓 MRI では心䇗性状を評価することが可能である. T2 強調画像では, 収縮障害を呈する部位に一致し て高頻度に心筋浮腫が認められる ${ }^{24)}$.Eite1 らは, 欧州，北アメリカ 7 施設 199 症例において，急性 期と慢性期に心臓 MRI を用いて評価を行った ${ }^{25)}$. その結果，急性期に $81 \%$ 症例で左室収縮障害を 呈する部位に心筋浮腫を認め，67\%の症例で急性
炎症の存在が示された。心襄液は $43 \%$ 症例に認 め，心筋に炎症を有する症例で多かった。左室内 血栓は $2 \%$ 症例で認めた。 そして, 慢性期に心 筋浮腫，心筋炎症は，ほとんど消失していること が明らかにされた。心臓 MRI による大規模研究に より，本症急性期に心筋炎症の存在が比較的高率 に示された。この事実は，たこつぼ型心筋症の病 因を考える上で重要である。従来，gadolinium

(Gd) 造影剤静注後の遅延造影 MRI による評価で, 遅延造影所見を認めないことが本症の特徵とさ れてきた. Eitel らは, 遅延造影 MRI において, 急性期心筋に $9 \%$ の症例で淡い遅延造影所見を認 めたと報告している ${ }^{25)}$ 。ただし，たこつぼ型心筋 症の遅延造影所見は, 急性心筋梗塞のような明瞭 な高信号でないため両者の鑑別は困難ではない. さらに, 心臓 MRI は右室機能評価や左室内血栓の 描出にも優れており, 本症の病態評価に大変有用 である。

\section{5 ）心臟カテーテル検査}

急性冠症候群を除外するため，急性期に冠動脈 造影検査を実施することが望ましい. Mayo Clinic の診断基準 ${ }^{14)}$ に, 急性のプラーク破綻を示唆する 冠動脈閉塞所見や造影所見を認めないことと記 載されていることもあり，わが国では冠動脈造影 検査が遵守されている。しかし，冠動脈造影検査 がリスクとなる症例も存在するため，心不全急性 期に無理な造影検査は控えるべきである，禁忌で ない限り左室造影検査が推奨される。急性期の左 室造影検査で, 壁運動異常のバリエーション評価 が可能であり, 心尖部型, 心室中部型, 心基部型, 局所型に分類される。心尖部型では収縮末期に典 型的なたこつぼ型の形態が見られる（Fig. 2）。

\section{予後，治療}

当初，たこつぼ型心筋症は予後良好な疾患と考 えられていたが，急性期に心原性ショック，心室 細動，全身塞栓症，稀に心破裂を起こして死亡す ることがあり決して予後良好なものばかりでは ない. 急性期院内死亡率は 4-5\%程度との報告が多 く，急性心筋梗塞の院内死亡率とほぼ同等である 26). 多くの場合は合併症なく経過するが，様々な 合併症が出現し心臓突然死をきたしうるため, 急 性心筋梗塞同様に厳重な管理が急性期に必要と 


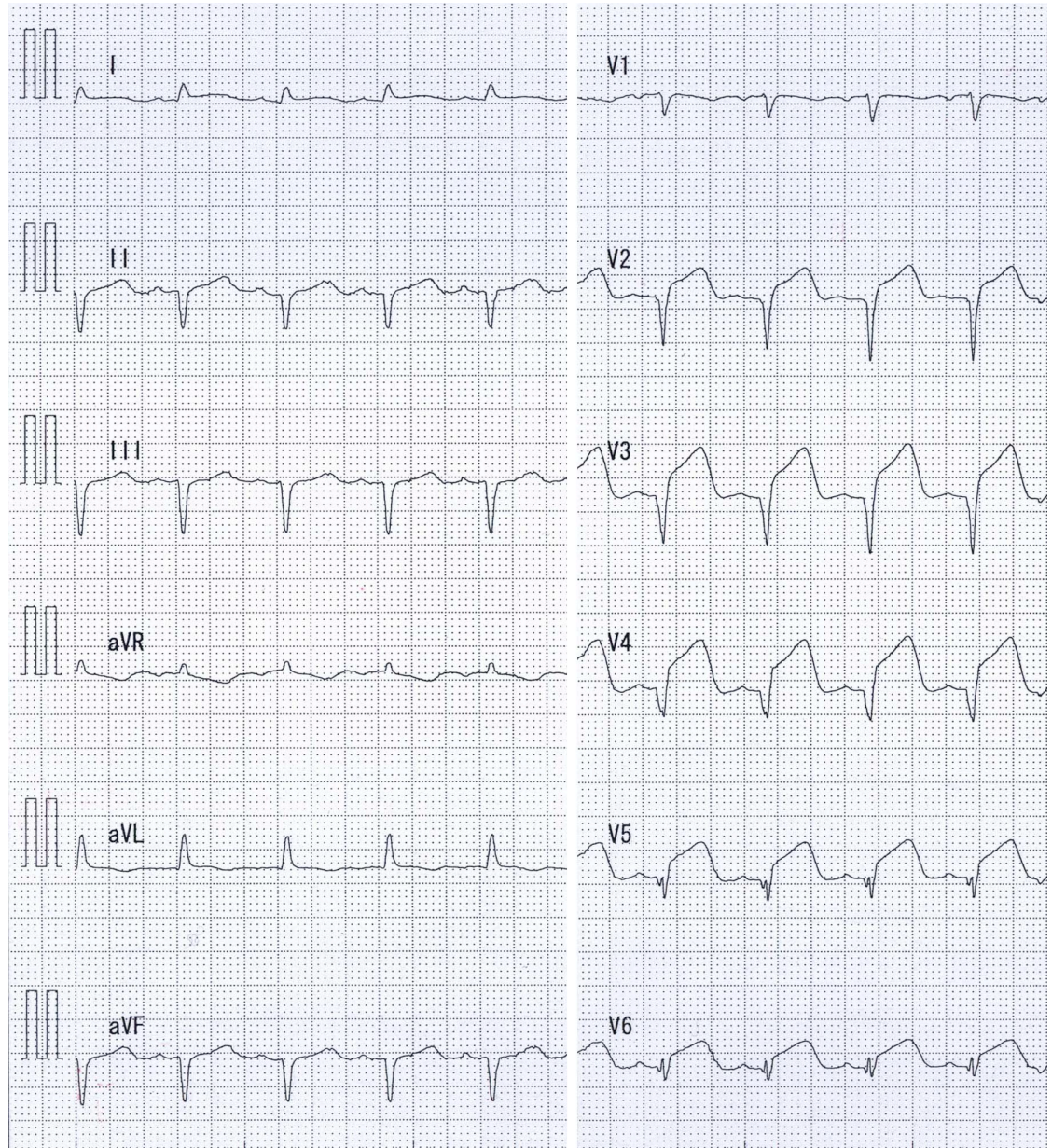

Fig. 1

Electrocardiogram in takotsubo cardiomyopathy of the apical type, showing ST-segment elevation in leads V2-6, and reciprocal ST-segment depression in lead aVR.

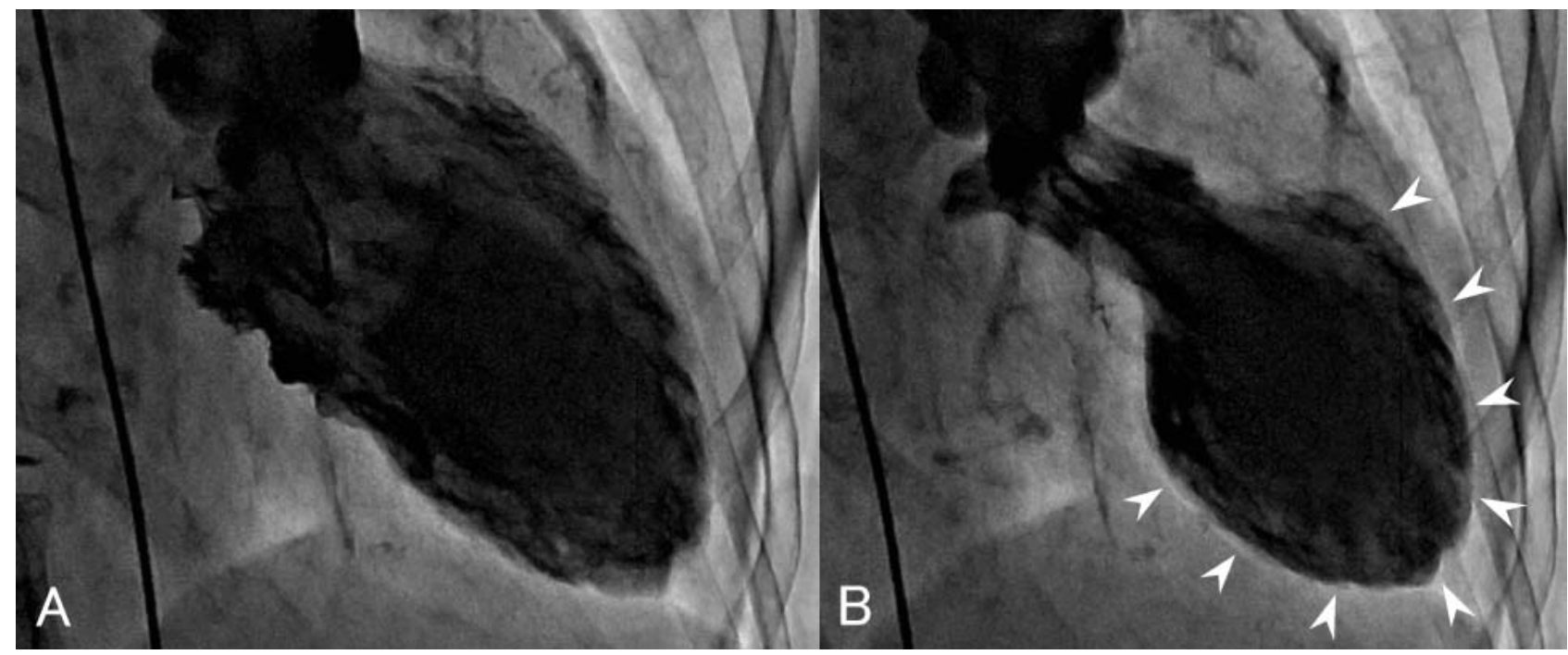

Fig. 2

Left ventriculography in takotsubo cardiomyopathy of the apical type, revealing akinesis of the mid and apical segments (arrows) with hyperdynamic basal contraction. (A) End-diastole; (B) end-systole. 
なる．本症は悪性疾患や重症疾患に合併すること もあり, その場合，予後は基礎疾患に左右される。 本症の治療法について統一した見解はないが，高 度の心不全例では強心薬や補助循環装置を必要 とすることも多い. 心不全の標準的治療薬である アンジオテンシン阻害薬， $\beta$ 遮断薬の本症に対す る効果は証明されていない。再発は $5 \%$ 程度と報 告されている。ストレスに対する応答様式は人そ れぞれであることから，確立された予防法はない． わが国未承認の levosimendan, 百日咳毒素がカテ コラミン誘発性心筋障害を予防する可能性が報 告されている.

\section{おわりに}

最近，捕獲筋症 (Capture myopathy) がヒトの ストレス性心筋症の自然界でのモデル ${ }^{27)}$ として 注目されている。暴れる動物を捕獲する際に跛行 や起立不能となる現象をいう。従来, たこつぼ型 心筀症の病態では心病変のみが注目されてきた が, 骨格筋一心臓連関の可能性も検討し病態を再 考する必要があるかもしれない。また，心臓 MRI による心筋性状評価から，本症の発症に心筋炎症 の存在が指摘されている ${ }^{25)}$ 。拡張型心筋症

(idiopathic dilated cardiomyopathy) の一部 は，病因として心筋炎の関与が示唆されており 28-30)，心筋炎症のメカニズムを探ることが本症の 発症機序を解明する上で重要と思われる。今後, ラット無動ストレス負荷モデル ${ }^{31)}$ など本症モデ ル動物を用いた研究の進展が期待される.

\section{謝辞}

本論文は, JSPS 科研費 JP16K09272 の助成を受 けたものです.

\section{文献}

1) Sato H, Uchida $T$, Dote $K$, et al.:

Tako-tsubo-like left ventricular dysfunction due to multivessel coronary spasm. In Kodama K, et al. (eds): Clinical aspect of myocardial injury: from ischemia to heart failure, pp56-64,

Kagakuhyoronsha Publishing, Tokyo, 1990. (in Japanese)
2) Dote K, Sato H, Tateishi H, et al.: Myocardial stunning due to simultaneous multivessel coronary spasms: a review of 5 cases. J Cardiol 21(2): 203-214, 1991. (in Japanese)

3) Tsuchihashi K, Ueshima K, Uchida T, et al.: Transient left ventricular apical ballooning without coronary artery stenosis: a novel heart syndrome mimicking acute myocardial infarction. J Am Coll Cardiol 8(1): 11-18, 2001.

4) Wittstein IS, Thiemann DR, Lima JA, et al.: Neurohumoral features of myocardial stunning due to sudden emotional stress. N Engl J Med 352(6): 539-548, 2005.

5) Paur H, Wright PT, Sikkel MB, et al.: High levels of circulating epinephrine trigger apical cardiodepression in a $\beta 2^{-}$adrenergic receptor/Gi-dependent manner : a new model of Takotsubo cardiomyopathy. Circulation 126:697-706, 2012.

6) Daaka Y, Luttrell LM, Lefkowitz RJ: Switching of the coupling of the beta 2adrenergic receptor to different $G$ proteins by protein kinase A. Nature 390: 88-91, 1997.

7) Suzuki H, Matsumoto Y, Kaneta T, et al.: Evidence for brain activation in patients with takotsubo cardiomyopathy. Circ J 78(1) : 256-258, 2014.

8) Yoshida T, Hibino T, Kako N, et al.: A pathophysiologic study of tako-tsubo cardiomyopathy with F-18 fluorodeoxyglucose positron emission tomography. Eur Heart J 28(21): 2598-2604, 2007.

9) von Korn H, Yu J, Lotze U, et al.: Tako-Tsubo-like cardiomyopathy: specific ECG findings, characterization and clinical findings in a European single center. Cardiology 112(1): 42-48, 2009.

10) Akashi YJ, Nakazawa K, Sakakibara M, et al.: The clinical features of takotsubo cardiomyopathy. QJM 96(8): 563-573, 2003. 
11) Nef HM, Möllmann H, Kostin S, et al.: Tako-Tsubo cardiomyopathy: intraindividual structural analysis in the acute phase and after functional recovery. Eur Heart J 28(20): 2456-2464, 2007.

12) Kawai S, Yamaguchi H, Suzuki H, et al.: Autopsy findings of takotsubo cardiomyopathy. Study report of the study group of idiopathic cardiomyopathy sponsored by the Health Welfare Ministry. 106-109, 2003. (in Japanese)

13) Kawai S, Kitabatake A, Tomoike H: Takotsubo Cardiomyopathy Group: Guidelines for diagnosis of takotsubo (ampulla) cardiomyopathy. Circ J 71: 990-992, 2007.

14) Prasad A, Lerman A, Rihal CS: Apical ballooning syndrome (Tako-Tsubo or stress cardiomyopathy): a mimic of acute myocardial infarction. Am Heart J 155(3): 408-417, 2008.

15) Lyon AR, Bossone E, Schneider B, et al.: Current state of knowledge on Takotsubo syndrome : a position statement from the task force on Takotsubo syndrome of the Heart Failure Association of the European Society of Cardiology. Eur J Heart Fail 18: 8-27, 2016.

16) Templin C, Ghadri JR, Diekmann J, et al.: Clinical features and outcomes of Takotsubo (stress) cardiomyopathy. N Engl J Med 373(10): 929-938, 2015.

17) Kato K, Kitahara H, Fujimoto $Y$, et al.: Prevalence and clinical features of focal Takotsubo cardiomyopathy. Circ J 80(8): 1824-1829, 2016.

18) Watanabe H, Kodama M, Okura $Y$, et al.: Impact of earthquakes on Takotsubo cardiomyopathy. JAMA $294: 305-307$, 2005.

19) El-Sayed AM, Brinjikji W, Salka S:

Demographic and co-morbid predictors of stress (takotsubo) cardiomyopathy. Am J Cardiol 110(9): 368-372, 2012.
20) Ahmed KA, Madhavan M, Prasad A: Brain natriuretic peptide in apical ballooning syndrome (Takotsubo/stress cardiomyopathy): comparison with acute myocardial infarction. Coron Artery Dis 23(4): 259-264, 2012.

21) Kosuge M, Ebina T, Hibi K, et al.: Simple and accurate electrocardiographic criteria to differentiate takotsubo cardiomyopathy from anterior acute myocardial infarction. J Am Coll Cardiol 55(22): 2514-2516, 2010.

22) Zorzi A, Baritussio A, ElMaghawry M, et al.: Differential diagnosis at admission between Takotsubo cardiomyopathy and acute apical-anterior myocardial infarction in postmenopausal women. Eur Heart J Acute Cardiovasc Care 5(4): 298-307, 2016.

23) Shimizu M, Nishizaki M, Yamawake N, et al.: J wave and fragmented QRS formation during the hyperacute phase in Takotsubo cardiomyopathy. Circ J 78(4): 943-949, 2014.

24) Mitchell JH, Hadden TB, Wilson JM, et al.: Clinical features and usefulness of cardiac magnetic resonance imaging in assessing myocardial viability and prognosis in Takotsubo cardiomyopathy (transient left ventricular apical ballooning syndrome). Am J Cardiol 100(2): 296-301, 2007.

25) Eitel I, von Knobelsdorff-Brenkenhoff F, Bernhardt $\mathrm{P}$, et al:: Clinical characteristics and cardiovascular magnetic resonance findings in stress (takotsubo) cardiomyopathy. JAMA 306(3): 277-286, 2011.

26) Singh K, Carson K, Shah R, et al.: Meta-analysis of clinical correlates of acute mortality in takotsubo cardiomyopathy. Am J Cardiol 113(8): 1420-1428, 2014.

27) Blumstein DT, Buckner J, Shah S, et al.: The evolution of capture myopathy in hooved mammals : a model for human stress cardiomyopathy? Evol Med Public Health 2015(1): 195-203, 2015.

28) Terasaki F, Okabe M, Hayashi T, et al.: 
Myocardial inflammatory cell infiltrates in cases of dilated cardiomyopathy : light

microscopic, immunohistochemical, and virological analyses of myocardium specimens obtained by partial left ventriculectomy. J Card Surg 14 (2) : 141-146, 1999.

29) Fujioka S, Kitaura Y, Ukimura A, et al.: Evaluation of viral infection in the myocardium of patients with idiopathic dilated cardiomyopathy. J Am Coll Cardiol 36(6): 1920-1926, 2000.

30) Fujioka S, Kitaura Y, Deguchi H, et al.: Evidence of viral infection in the myocardium of American and Japanese patients with idiopathic dilated cardiomyopathy. Am J Cardiol 94(5): 602-605, 2004.

31) Ueyama T, Kasamatsu K, Hano T, et al.: Emotional stress induces transient left ventricular hypocontraction in the rat via activation of cardiac adrenoceptors -a possible animal model of tako-tsubo cardiomyopathy. Circ J 66: 712-713, 2002. 